\title{
Adsorption isotherms of the red mombin powder produced in spouted bed dryer
}

\author{
Analha D. F. Lins ${ }^{1}$, Ana P. T. Rocha ${ }^{2}$, Josivanda P. Gomes ${ }^{1}$, \\ Regilane M. Feitosa ${ }^{3}$, Gilmar T. Araujo ${ }^{4}$ \& Dyego da C. Santos ${ }^{1}$
}

\footnotetext{
${ }^{1}$ Universidade Federal de Campina Grande/Centro de Tecnologia e Recursos Naturais/Unidade Acadêmica de Engenharia Agrícola. Campina Grande, PB. E-mail: dyallalins@gmail.com; josivanda@gmail.com (Corresponding author); dyego.csantos@gmail.com

${ }^{2}$ Universidade Federal de Campina Grande/Centro de Tecnologia e Recursos Naturais/Unidade Acadêmica de Engenharia de Alimentos. Campina Grande, PB. E-mail: anatrindade@deag.ufcg.edu.br

${ }^{3}$ Universidade Federal de Campina Grande/Centro de Ciências e Tecnologia/Programa de Pós-graduação em Engenharia de Processos. Campina Grande, PB. E-mail: regilanemarques@yahoo.com.br

${ }^{4}$ Universidade Federal de Campina Grande/Centro de Tecnologia e Recursos Naturais/Unidade Acadêmica de Engenharia Química. Campina Grande, PB. E-mail: gilmartrindade@ufcg.edu.br
}

\section{Key words:}

Spondias purpurea L. drying hygroscopicity

\begin{abstract}
A B S T R A C T
Red mombin is a seasonal fruit and susceptible to degradation reactions due to its high water content. This highlights the need to use processes that prolong its life and make it available all year round, including to markets away from the production sites. Thus, the objective of this study was to produce red mombin pulp powder in spouted bed dryer, evaluate it regarding physical and chemical parameters and assess its hygroscopic behavior at temperatures of 20 , 30 and $40{ }^{\circ} \mathrm{C}$, fitting the models of the GAB, Oswin and Peleg to the experimental data. The results of the physical and chemical analyses showed intermediate wetting time of $0.39 \mathrm{~g} \mathrm{~min}^{-1}$, solubility higher than $60 \%$ and mean flowability with Hausner ratio and Carr index of 1.26-1.34 and $0.21-0.25$, respectively. The powder particles exhibited spherical shape, smooth surface and some irregularities, with tendency to form agglomerates. The isotherms had a type-II sigmoidal behavior, and the Peleg model, at all temperatures, showed the best fits to the experimental data with determination coefficients above 0.99 and mean percentage deviations lower than $2.0 \%$.
\end{abstract}

\section{Isotermas de adsorção do pó de seriguela produzido em secador de leito de jorro}

\section{R E S U M O}

A seriguela é um fruto sazonal e susceptível a reações de deterioração devido ao seu elevado teor de água, o que evidencia a necessidade de utilização de processos que prolonguem sua vida útil e a disponibilize durante todo o ano, inclusive a mercados distantes dos locais de produção. Assim, objetivou-se produzir a polpa de seriguela em pó em secador de leito de jorro, analisá-la quanto aos parâmetros físicos e químicos e avaliar seu comportamento higroscópico nas temperaturas de 20,30 e $40{ }^{\circ} \mathrm{C}$, com ajustes dos modelos de GAB, Oswin e Peleg aos dados experimentais. Os resultados das análises físicas e químicas evidenciaram tempo de molhagem intermediário, de $0,39 \mathrm{~g} \mathrm{~min}^{-1}$, solubilidade superior a $60 \%$ e média fluidez com fator de Hausner e índice de Carr compreendido entre 1,26-1,34 e 0,21-0,25, respectivamente. As partículas de pó se apresentaram com formato esférico, superfície lisa e algumas irregularidades, com tendência de formação de aglomerados. As isotermas tiveram comportamento sigmoidal do tipo II, com o modelo de Peleg detendo, em todas as temperaturas, os melhores ajustes aos dados experimentais com coeficientes de determinação superiores a 0,99 e desvios percentuais médios inferiores a 2,0\%. 


\section{INTRODUCTION}

Red mombin (Spondias purpurea L.) is an exotic fruit, composed of nutritious substances such as minerals, carbohydrates and phenolic compounds (Todisco et al., 2015), being widely appreciated by consumers due to its sensory characteristics. However, for being climacteric and having high water content, it becomes perishable and this fact leads to large losses during the season. Hence, the drying process is an alternative to extend its lifespan, since the reduction of water content minimizes biochemical reactions, increasing the stability of the material during the storage. In addition, the dehydration facilitates handling and transport, being also one more option of raw material in the market (Santos et al., 2016).

Among the drying methods that can be used, the method processed in spouted bed dryer has stood out as good alternative to produce powders with fine granulometries, uniform and of high quality, with short time of contact between pulp, particles and temperature, resulting in greater retention of thermo-sensitive compounds due to the utilization of lower temperatures, compared with the spray drying process (Osório et al., 2011).

In this context, this study aimed to produce red mombin pulp powder in spouted bed dryer, analyze it regarding physical and chemical parameters and evaluate its hygroscopic behavior at the temperatures of 20,30 and $40{ }^{\circ} \mathrm{C}$, adjusting the models of GAB, Oswin and Peleg to the experimental data.

\section{Material ANd Methods}

The experiments used ripe red mombins purchased in the local market and maltodextrin with dextrose equivalent $(\mathrm{DE})$ of 10 as drying adjuvant. The fruits were sent to the Laboratory of Processing and Storage of Agricultural Products of the Federal University of Campina Grande, selected, washed in running water to remove dirt and sanitized in 50-ppm sodium hypochlorite solution for $15 \mathrm{~min}$. Fruits were pulped in an industrial pulping machine (Laboremus, model DF-200) with capacity for $400 \mathrm{~kg} \mathrm{~h}^{-1}$, and the pulp was refined in $2.5-\mathrm{mm}$ mesh sieve, placed in polyethylene bags, frozen and stored at $-18^{\circ} \mathrm{C}$, until the utilization in the experiments.

For dehydration, the pulp was previously thawed under refrigeration $\left(4 \pm 2{ }^{\circ} \mathrm{C}\right)$ and formulated with $3 \%$ of maltodextrin, using a spouted bed dryer (Labmaq do Brasil, model FBD 1.0) operating at $80^{\circ} \mathrm{C}$, with minimum spout of $2.5 \mathrm{~m}^{3} \mathrm{~min}^{-1}$, suspension flow rate of the atomizing nozzle of $2 \mathrm{~mL} \mathrm{~min}{ }^{-1}$, internal pressure of 3 bar and pump with flow rate of $3 \mathrm{~mL} \mathrm{~min}^{-1}$. The bed of inert particles comprised type849 polystyrene particles. The pulp was collected in a glass container attached to the outlet of the cyclone.

The produced powder was characterized in triplicate for the parameters wettability (Freudig et al.,1999), solubility (CanoChauca et al., 2005), apparent density, compact density, Hausner ratio and Carr index (Yusof et al., 2012). The content of total phenolic compounds was determined in spectrophotometer (Agilent Technologies Cary 60 UV-Vis) according to the FolinCiocalteu method described by Waterhouse \& Laurie (2006). The antioxidant capacity of the free radical ABTS (2,2'azino- bis-(3-ethylbenzothiazoline-6-sulfonic acid)) was determined according to Rufino et al. (2010).

The morphological analysis of the particles was performed in the high-power optical microscope Hirox, model KH1300, equipped with the lenses MXG-5040RZ and MX-10C, and operating with the software 2D MEASURE. To obtain the images, red mombin powder was photographed with magnifications of $350 \times, 1400 \times, 2100 \times$ and $3500 \times$.

The adsorption isotherms of the powder samples were determined through the indirect static method (Crapiste \& Rotstein, 1982) in BOD (Biochemical Oxygen Demand) chamber regulated at temperatures of 20,30 and $40{ }^{\circ} \mathrm{C}$, with measurements of water activity $\left(a_{w}\right)$ in hygrometer (Aqualab $3 \mathrm{TE}$, Decagon) in variation range of approximately $0.3-0.9$. The water content was determined in an oven at $105^{\circ} \mathrm{C}$ for $24 \mathrm{~h}$.

The mathematical models of GAB (Syamaladevi et al., 2009), Oswin (Bezerra et al., 2010) and Peleg (Silva et al., 2015), respectively represented by Eqs. 1, 2 and 3, were fitted to the experimental data of water adsorption isotherms of red mombin powders through nonlinear regression, by the Quasi-Newton method, using the program Statistica 7.0, of the Statsoft Inc. (Tulsa, OK, USA).

$$
\begin{gathered}
\mathrm{X}_{\mathrm{eq}}=\frac{\mathrm{x}_{\mathrm{m}} \mathrm{CKa}_{\mathrm{w}}}{\left(1-\mathrm{ka}_{\mathrm{w}}\right)\left(1-\mathrm{ka}_{\mathrm{w}}+\mathrm{Cka}_{\mathrm{w}}\right)} \\
\mathrm{X}_{\mathrm{eq}}=\mathrm{a}\left(\frac{\mathrm{a}_{\mathrm{w}}}{\left(1-\mathrm{a}_{\mathrm{w}}\right)}\right)^{\mathrm{b}} \\
\mathrm{X}_{\mathrm{eq}}=\mathrm{k}_{1} \mathrm{a}_{\mathrm{w}}^{\mathrm{n}_{1}}+\mathrm{k}_{2} \mathrm{a}_{\mathrm{w}}^{\mathrm{n}_{2}}
\end{gathered}
$$

where:

$\mathrm{X}_{\mathrm{eq}}$ - equilibrium moisture content, $\mathrm{kg} \mathrm{kg}^{-1}$ on dry basis;

$\mathrm{X}_{\mathrm{m}}$ - moisture content in the molecular monolayer, $\mathrm{kg} \mathrm{kg}^{-1}$ on dry basis;

$\mathrm{a}_{\mathrm{w}} \quad$ - water activity, dimensionless; and,

$\mathrm{k}_{1}, \mathrm{k}_{2}, \mathrm{n}_{1}, \mathrm{n}_{2}, \mathrm{C}, \mathrm{K}, \mathrm{a}, \mathrm{b}$ - constants of the equations.

The criteria used to determine the best fit of the models to the isotherms were the coefficients of determination $\left(\mathrm{R}^{2}\right)$ and mean percentage deviation $(\mathrm{P})$, which was calculated according to Eq. 4:

$$
\mathrm{P}=\frac{100}{\mathrm{n}} \sum_{\mathrm{i}=1}^{\mathrm{n}} \frac{\left|\left(\mathrm{X}_{\text {exp }}-\mathrm{X}_{\text {teor }}\right)\right|}{\mathrm{X}_{\text {exp }}}
$$

where:

$\mathrm{P} \quad$ - mean percentage deviation (\%);

$X_{\text {exp }}$ - Values obtained experimentally;

$\mathrm{X}_{\text {teor }}$ - Values predicted by the model; and,

$n$ - number of experimental data.

\section{Results AND Discussion}

Table 1 shows the results of physical and chemical characteristics of red mombin powder produced in spouted 
Table 1. Physical and chemical characteristics of red mombin pulp powder produced in spouted bed

\begin{tabular}{|c|c|}
\hline Physical properties & Mean value \\
\hline Wettability $\left(\mathrm{g} \mathrm{min}^{-1}\right)$ & $0.39 \pm 0.01$ \\
\hline Solubility (\%) & $63.16 \pm 1.25$ \\
\hline Apparent density $\left(\mathrm{g} \mathrm{mL}^{-1}\right)$ & $0.47 \pm 0.01$ \\
\hline Compact density $\left(\mathrm{g} \mathrm{mL}^{-1}\right)$ & $0.61 \pm 0.02$ \\
\hline \multicolumn{2}{|l|}{ Chemical properties } \\
\hline Hausner ratio & $1.30 \pm 0.01$ \\
\hline Carr index & $0.23 \pm 0.01$ \\
\hline Phenolic compounds (mg of GAE. $100 \mathrm{~g}^{-1}$ ) & $396.20 \pm 6.41$ \\
\hline Antioxidants $\left(\mu \mathrm{M}\right.$ of Trolox $\left.\mathrm{g}^{-1}\right)$ & $1.73 \pm 0.01$ \\
\hline
\end{tabular}

bed dryer. Water penetration in the structure of the powder indicated intermediate speed for the complete wetting of the particles; hence, it could favor the formation of lumps during the mixture with water, which is probably related to the low concentration of maltodextrin (3\%) and to the chemical composition of red mombin, which, for having high concentration of sugars, tends to form agglomerates and, consequently, obstruct the interstitial spaces that are important for water penetration. Solubility was close to the value reported by Liu et al. (2010) in tomato powder (60\%), possibly related to the presence of insoluble pigments and fibers, and pectic material. The soluble portion, which was higher than $60 \%$, is directly related to sugars, organic acids and soluble fibers.

Apparent density was close to the values reported by Oliveira et al. (2013) in strawberry powders obtained by spray drying atomization, with 0.40 and $0.47 \mathrm{~g} \mathrm{~mL}^{-1}$, which represents, from the practical point of view, reduction in the cost of packaging material and transport, and the higher the density, the greater the saving (Michalska et al., 2016). The density increased about $30 \%$ after compaction, related to the high porosity of dehydrated products. After disturbed, fruit powders tend to rearrange so that their particles occupy the interstitial spaces, with consequent increase of density.

According to the classification proposed by Quispe-Condori et al. (2011), red mombin pulp powder was classified as of intermediate flowability for showing values of Hausner ratio and Carr index of 1.26-1.34 and 0.21-0.25, respectively, which may lead to difficulty of flow, since the dehydrated product often remains exposed to the environmental conditions with consequent increase in the cohesion of the powder particles due to the presence of sugars.

Despite the possibility of destruction of phenolic compounds by the action of temperature, the red mombin pulp powder showed high content of this constituent, being also higher than that reported by Todisco et al. (2015) in red mombin pulp atomized in spray dryer, corresponding to

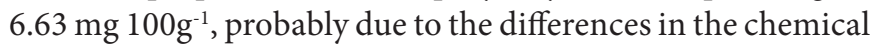
composition of the utilized raw material, which is a function of the edaphoclimatic factors. Oliveira et al. (2013), lyophilizing strawberry pulp with maltodextrin (10 DE), obtained value of $50.17 \mu \mathrm{M} 100 \mathrm{~g}^{-1}$ of antioxidant, which is higher than that found in the present study.

Figure $1(\mathrm{~A}, \mathrm{~B}, \mathrm{C}, \mathrm{D})$ shows the morphology of red mombin powder produced in spouted bed dryer. In general, the microparticles showed predominant diameter between 10 and $20 \mu \mathrm{m}$, spherical shape with smooth surface, with trend of formation of structural agglomerates and with some irregularities possibly attributed to the friction of the inert particles with the red mombin powder inside the drying chamber. Cano-Chauca et al. (2005) observed, in mango pulp powder obtained through spray drying, that the treatment using maltodextrin as carrier agent and addition of cellulose for the levels $0,3,6$ and $9 \%$, caused some divisions in the particles.

Osório et al. (2011) reported that the formation of smooth spheres is desirable for the stability of dehydrated fruits. In the encapsulation, as the particles are thrown in the gaseous medium, they become spherical, as observed in Figure 1. It is observed that the particles are agglomerated because, in general, the powder is a highly hygroscopic material. A similar result was reported by Ferrari et al. (2012), producing blackberry powder in spray dryer, in which the sample showed strong adhesion of small particles on the surface of larger particles, with consequent formation of agglomerate.

Although the red mombin powder tended to form spherical particles, there was irregularity in some structures, such as size and shape (Figure 1D), probably associated with the mechanical deformation of the coating pellicle due to the friction between particles and the drying chamber wall, as reported by Costa et al. (2015) in 'açaí' powder obtained in spouted bed. Bezerra et al. (2013) also noted this behavior of irregularities, studying the starch granules of green banana dried in spouted bed.

Table 2 shows the values of the parameters of the mathematical models of GAB, Oswin and Peleg adjusted to the experimental data of water adsorption isotherms of red mombin powder at temperatures of 20,30 and $40{ }^{\circ} \mathrm{C}$, with their respective coefficients of determination $\left(\mathrm{R}^{2}\right)$ and mean percentage deviations $(\mathrm{P})$. All models showed $\mathrm{R}^{2}$ above 0.99 and $\mathrm{P}$ values lower than $10 \%$, indicating good representability of the investigated phenomenon.
A.

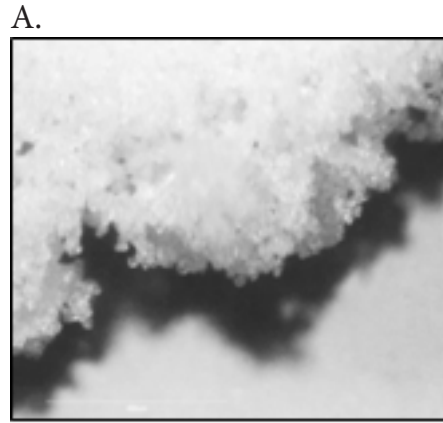

B.

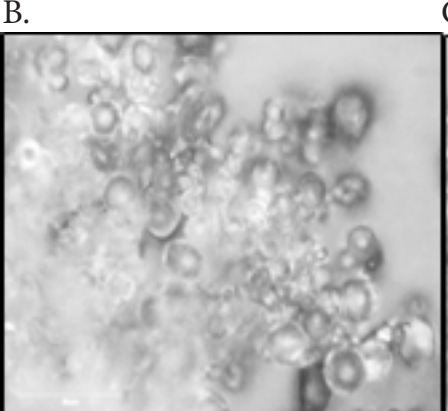

C.

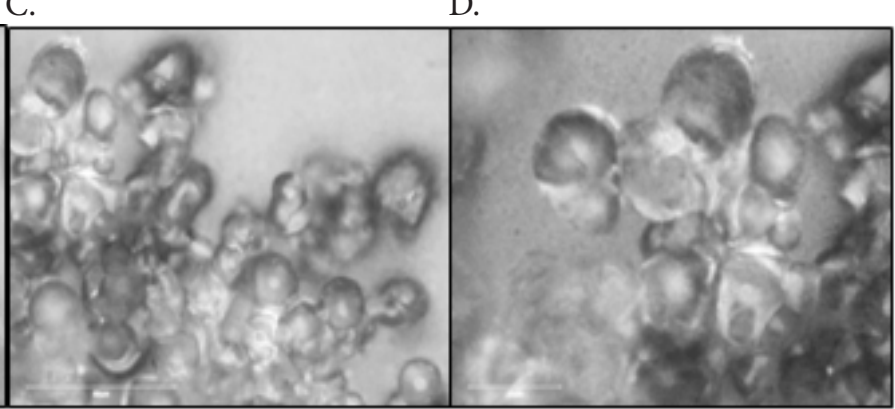

Figure 1. Morphology of red mombin pulp powder produced in spouted bed in the magnifications of $350 \times(\mathrm{A}), 1400 \times$ (B); $2100 \times(C)$ and $3500 \times(\mathrm{D})($ diameter in $\mu \mathrm{m})$ 
Table 2. Parameters of the adjusted mathematical models with their respective coefficients of determination $\left(R^{2}\right)$ and mean percentage deviations $(\mathrm{P})$ of water adsorption isotherms of red mombin powder produced in spouted bed

\begin{tabular}{|c|c|c|c|c|c|c|c|}
\hline \multirow{2}{*}{ Model } & \multirow{2}{*}{$\begin{array}{c}\text { Temperature } \\
\left({ }^{\circ} \mathrm{C}\right)\end{array}$} & \multicolumn{4}{|c|}{ Parameters } & \multirow{2}{*}{$\mathbf{R}^{2}$} & \multirow{2}{*}{$\begin{array}{c}P \\
(\%)\end{array}$} \\
\hline & & $\mathbf{X}_{\mathrm{m}}$ & & & K & & \\
\hline \multirow{3}{*}{$\mathrm{GAB}$} & 20 & 11.5353 & & & 0.9132 & 0.9924 & 1.38 \\
\hline & 30 & 9.5797 & & & 0.9491 & 0.9935 & 1.75 \\
\hline & 40 & 10.07239 & & & 0.9535 & 0.9944 & 2.94 \\
\hline & & \multicolumn{2}{|c|}{$a$} & \multicolumn{2}{|c|}{ b } & & \\
\hline \multirow{4}{*}{ Oswin } & 20 & \multicolumn{2}{|c|}{21.3175} & \multicolumn{2}{|c|}{0.5010} & 0.9924 & 4.39 \\
\hline & 30 & \multicolumn{2}{|c|}{17.5067} & \multicolumn{2}{|c|}{0.5943} & 0.9908 & 4.53 \\
\hline & 40 & \multicolumn{2}{|c|}{19.0567} & \multicolumn{2}{|c|}{0.5911} & 0.9910 & 7.36 \\
\hline & & $k_{1}$ & $\mathrm{n}_{1}$ & $k_{2}$ & $\mathrm{n}_{2}$ & & \\
\hline \multirow{3}{*}{ Peleg } & 20 & 100.8124 & 11.8797 & 40.0538 & 0.7591 & 0.9995 & 0.84 \\
\hline & 30 & 124.5281 & 12.6002 & 37.3803 & 0.8637 & 0.9991 & 1.65 \\
\hline & 40 & 144.7519 & 13.2717 & 38.8672 & 0.8135 & 0.9995 & 1.56 \\
\hline
\end{tabular}

The highest moisture content in the molecular monolayer $\left(\mathrm{X}_{\mathrm{m}}\right)$ of the GAB model was obtained at the temperature of $20{ }^{\circ} \mathrm{C}$, indicating that under this condition the sample has stability in a wider range of moisture content, since at moisture contents lower than $\mathrm{Xm}$ the deterioration reactions are minimal, because the water is strongly bound to the powder. According to Comunian et al. (2011), this content corresponds to the amount of water strongly adsorbed to specific sites on the surface of the foods, considering a critical value above which the rates of some degradation reactions increase and the stability of the food matrix decreases.

Since the parameters $\mathrm{C}$ and $\mathrm{K}$ are indicative of the type of isotherm, the red mombin powder was classified as type II, because the GAB model showed $K$ values between 0 and 1.0, and $\mathrm{C}$ values higher than 2.0, in agreement with the classification for pulp powders of the mango varieties 'Coite' and 'Espada' (Bezerra et al., 2010). Oliveira et al. (2006) report that these curves are typical of products with large amounts of sugar and solutes, and with low adsorption through capillarity, being characteristic of most foods (Bezerra et al., 2010).

The parameter $\mathrm{K}$ of the GAB model increased with the increments of temperature, fitting in the range reported by Syamaladevi et al. (2009), between 0.7 and 1.0 for food materials. According to Alexandre et al. (2007), this parameter represents the correction factor of properties of the molecules in the multilayer with respect to the volume of the liquid, while the sorption constant $\mathrm{C}$ is a function of the interactions between the active sites of the product and the water molecules.

In the model of Oswin, the lowest value of the constant ' $a$ ' (17.5067) and highest value of ' $b$ ' (0.5943) were obtained at the temperature of $30^{\circ} \mathrm{C}$, which was also observed by Moreira et al. (2013), analyzing the hygroscopic behavior of mango powder obtained through lyophilization. According to Alcântara et al. (2009), for a good representation of the adsorption isotherms of a food, the values of the parameter 'a' in the Oswin model must be higher than zero and those of ' $b$ ' must be between zero and 1.0; this model satisfactorily fitted to the experimental data. According to Blahovec (2004), when these parameters are within these intervals, it is an indication that there is no point of inflection in the curve and, consequently, there are no changes in the concavity of the functions; thus, the estimated parameters have mathematical and physical consistency.

Among the studied equations, the Peleg model was selected as the best one to represent red mombin powder hygroscopicity, due to the best statistical criteria $\mathrm{R}^{2}$ and $\mathrm{P}$. This model also resulted in the best fits to the experimental data of 'umbu-cajá' powder analyzed by Silva et al. (2015). The parameter $\mathrm{k}_{1}$ of this model increased as the temperature increased, indicating that at $20^{\circ} \mathrm{C}$ there was higher initial rate of water absorption.

Figure 2 shows the curves of water adsorption isotherms of red mombin powder at the temperatures of 20,30 and 40 ${ }^{\circ} \mathrm{C}$ fitted by the Peleg model. There was an increase in water activity always when the equilibrium water content increased, a behavior also found by Silva et al. (2015), studying the water adsorption isotherms of 'umbu-cajá' powder. At the lowest temperature, water activity values tended to be higher, for the $a_{w}$ range of up to 0.85 . According to Goula et al. (2008), temperature affects the mobility of water molecules and the equilibrium between vapor and the adsorbed phase. In general, an increment of temperature causes reduction in the equilibrium moisture content, which can be attributed to the decrease in the total number of active sites available for binding to the water molecule, due to changes of physical and/ or chemical nature.

There was a sharp increase in $\mathrm{a}_{\mathrm{w}}$ values at the beginning of the process, while the equilibrium moisture content showed a smaller increment (Figure 2). The isotherms were well-defined and crossed in the $\mathrm{a}_{\mathrm{w}}$ of approximately 0.85 . From this point on, small increments of $\mathrm{a}_{\mathrm{w}}$ caused higher equilibrium moisture content, followed by the isotherms at 30 and $20^{\circ} \mathrm{C}$. For Gioielli

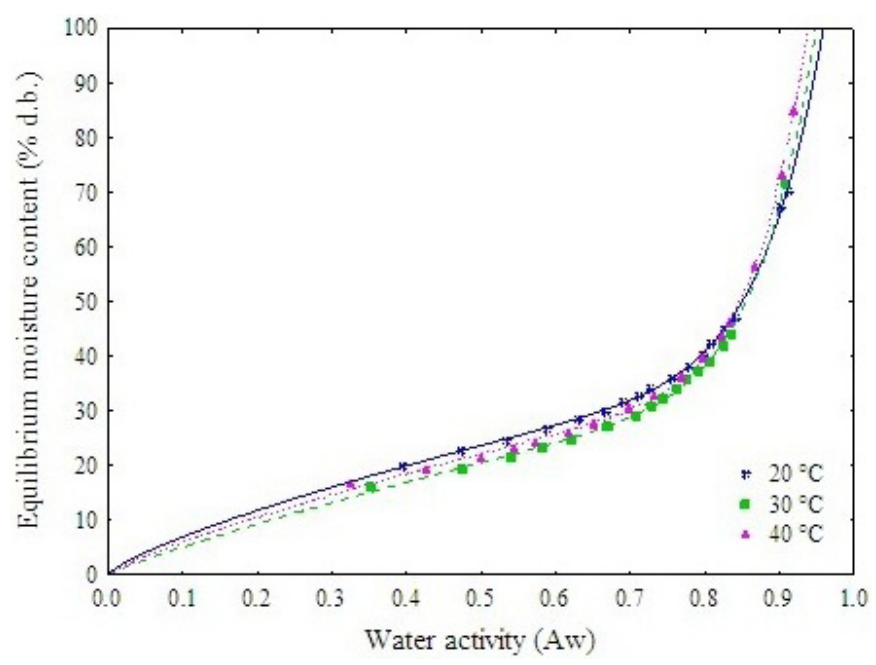

Figure 2. Water adsorption isotherms of red mombin powder fitted by the Peleg model 
\& Pitombo (1998), there is always cross between the curves in the range of high $a_{w}$ in powders rich in sugar, and this result was also reported by Alexandre et al. (2007) in 'pitanga' powder. At the highest equilibrium moisture content, the red mombin powder obtained, for all temperatures evaluated, $a_{w}$ values higher than 0.90 , probably related to the hydrophilic characteristic of the sugars of the fruit.

\section{Conclusions}

1. The powder showed intermediate wetting time, $0.39 \mathrm{~g} \mathrm{~min}^{-1}$, solubility higher than $60 \%$, intermediate flowability with Hausner ratio and Carr index of 1.26-1.34 and 0.21-0.25, respectively, and considerable concentration of phenolic compounds, higher than 390 mg GAE $100 \mathrm{~g}^{-1}$.

2. The red mombin powder obtained in spouted bed, in general, showed spherical shape, smooth surface and with trend to form agglomerates.

3. The equilibrium moisture content of red mombin powder is directly proportional to the water activity; the Peleg model showed the best fits to the experimental data and the isotherms were classified as type-II sigmoidal, characteristic of foods with large amounts of sugars.

\section{Literature Cited}

Alcântara, S. R.; Almeida, F. de A. C.; Silva, F. L. H. da; Gomes, J. P. Isotermas de adsorção do pedúnculo seco do caju. Revista Brasileira de Engenharia Agrícola e Ambiental, v.13, p.81-87, 2009. https://doi.org/10.1590/S1415-43662009000100012

Alexandre, H. V.; Figueirêdo, R. M. F. de; Queiroz, A. J. de M. Isotermas de adsorção de umidade da pitanga em pó. Revista de Biologia e Ciências da Terra, v.7, p.1-11, 2007.

Bezerra, C. V.; Amante, E. R.; Oliveira, D. C. de; Rodrigues, A. M. C.; Silva, L. H. M. da. Green banana (Musa cavendishii) flour obtained in spouted bed - Effect of drying on physico-chemical, functional and morphological characteristics of the starch. Industrial Crops and Products, v.41, p.241-249, 2013. https://doi.org/10.1016/j. indcrop.2012.04.035

Bezerra, T. S.; Costa, J. M. C. da; Afonso, M. R. A.; Maia, G. A.; Rocha, E. M. de F. F. Comportamento higroscópico de pós de manga das variedades coité e espada e avaliação das características físicoquímicas. Ciência Rural, v.40, p.2186-2192, 2010. https:/doi. org/10.1590/S0103-84782010005000164

Blahovec, J. Sorption isotherms in materials of biological origin mathematical and physical approach. Journal of Food Engineering, v.65, p.489-495, 2004. https://doi.org/10.1016/j. jfoodeng.2004.02.012

Cano-Chauca, M.; Stringheta, P. C.; Ramos, A. M.; Cal-Vidal, J. Effect of the carriers on the microstructure of mango powder obtained by spray drying and its functional characterization. Innovative Food Science \& Emerging Technologies, v.6, p.420-428, 2005. https://doi.org/10.1016/j.ifset.2005.05.003

Crapiste, G. H.; Rotstein, E. Prediction of sorptional equilibrium data for starch-containing foodstuffs. Journal of Food Science, v.47, p.1501-1507, 1982. https://doi.org/10.1111/j.1365-2621.1982. tb04970.x
Comunian, T. A.; Monterrey-Quintero, E. S.; Thomazini, M.; Balieiro, J. C. C.; Piccone, P.; Pittia, P.; Favaro-Trindade, C. S. Assessment of production efficiency, physicochemical properties and storage stability of spray-dried chlorophyllide, a natural food colourant, using gum Arabic, maltodextrin and soy protein isolate-based carrier systems. International Journal of Food Science and Technology, v.46, p.1259-1265, 2011. https://doi.org/10.1111/j.1365-2621.2011.02617.x

Costa, R. G.; Andreola, K.; Mattietto, R. de A.; Faria, L. J. G. de; Taranto, O. P. Effect of operating conditions on the yield and quality of açai (Euterpe oleracea Mart.) powder produced in spouted bed. LWT-Food Science and Technology, v.64, p.11961203, 2015. https://doi.org/10.1016/j.lwt.2015.07.027

Ferrari, C. C.; Germer, S. P. M.; Alvim, I. D.; Vissotto, F. Z.; Aguirre, J. M. de. Influence of carrier agents on the physicochemical properties of blackberry powder produced by spray drying. International Journal of Food Science \& Technology, v.47, p.12371245, 2012. https://doi.org/10.1111/j.1365-2621.2012.02964.x

Freudig, B.; Hogekamp, S.; Schubert, H. Dispersion of powders in liquids in stirred vessel. Chemical Engineering and Processing, v.38, p.525-532, 1999. https://doi.org/10.1016/S0255-2701(99)00049-5

Gioielli, L. A.; Pitombo, R. N. M. Conservação de alimentos pelo controle da umidade. In: Baruffaldi, R.; Oliveira, M. N. Fundamentos de tecnologia de alimentos. São Paulo: Atheneu, 1998. p.123-152.

Goula, A. M.; Karapantsios, T. D.; Achilias, D. S.; Adamopoulos, K. G. Water sorption isotherms and glass transition temperature of spray dried tomato pulp. Journal of Food Engineering, v.85, p.73-83, 2008. https://doi.org/10.1016/j.jfoodeng.2007.07.015

Liu, F.; Cao, X.; Wang, H.; Liao, X. Changes of tomato powder qualities during storage. Powder Technology, v.204, p.159-166, 2010. https://doi.org/10.1016/j.powtec.2010.08.002

Michalska, A.; Wojdyło, A.; Lech, K.; Łysiak, G.; Figiel, A. Physicochemical properties of whole fruit plum powders obtained using different drying technologies. Food Chemistry, v.207, p.223-232, 2016. https://doi.org/10.1016/j.foodchem.2016.03.075

Moreira, T. B.; Rocha, E. M. F. F.; Afonso, M. R. A.; Costa, J. M. C. da. Comportamento das isotermas de adsorção do pó da polpa de manga liofilizada. Revista Brasileira de Engenharia Agrícola e Ambiental, v.17, p.1093-1098, 2013. https://doi.org/10.1590/ S1415-43662013001000011

Oliveira, M. I. S.; Tonon, R. V.; Nogueira, R. I.; Cabral, L. M. C. Estabilidade da polpa de morango atomizada utilizando diferentes agentes carreadores. Brazilian Journal of Food Technology, v.16, p.310-318, 2013. https://doi.org/10.1590/S198167232013005000037

Oliveira, M. M. de; Campos, A. R. N.; Dantas, J. P.; Gomes, J. P.; Silva, F. L. H. da. Isotermas de dessorção da casca do maracujá (Passiflora edulis Sims): Determinação experimental e avaliação de modelos matemáticos. Ciência Rural, v.36, p.1624-1629, 2006. https://doi. org/10.1590/S0103-84782006000500045

Osório, C.; Forero, D. P.; Carriazo, J. G. Characterisation and performance assessment of guava (Psidium guajava L.) microencapsulates obtained by spray-drying. Food Research International, v.44, p.1174-1181, 2011. https://doi.org/10.1016/j.foodres.2010.09.007

Quispe-Condori, S.; Saldaña, M. D. A.; Temelli, F. Microencapsulation of flax oil with zein using spray and freeze drying. LWT - Food Science and Technology, v.44, p.1880-1887, 2011. https://doi. org/10.1016/j.lwt.2011.01.005 
Rufino, M. S. M.; Alves, R. E.; Brito, E. S. de; Perez-Jimenez, J.; SauraCalixto, F.; Mancini Filho, J. Bioactive compounds and antioxidant capacities of 18 non-traditional tropical fruits from Brazil. Food Chemistry, v.121, p.996-1002, 2010. https://doi.org/10.1016/j. foodchem.2010.01.037

Santos, D. da C.; Rocha, A. P. T.; Gomes, J. P.; Oliveira, E. N. A. de; Albuquerque, E. M. B. de; Araujo, G. T. de. Storage of 'umbucajá pulp powder produced by lyophilization. Revista Brasileira de Engenharia Agrícola e Ambiental, v.20, p.1118-1123, 2016. https://doi.org/10.1590/1807-1929/agriambi.v20n12p1118-1123 Silva, R. N. G.; Figueirêdo, R. M. F. de; Queiroz, A. J. de M.; Feitosa, R. M. Isotermas de adsorção de umidade do umbu-cajá em pó. Revista Educação Agrícola Superior, v.30, p.33-36, 2015. https:// doi.org/10.12722/0101-756X.v30n01a07
Syamaladevi, R. M.; Sablani, S. S.; Tang, J.; Powers, J.; Swanson, B. G. State diagram and water adsorption isotherm of raspberry (Rubus idaeus). Journal of Food Engineering, v.91, p.460-467, 2009. https://doi.org/10.1016/j.jfoodeng.2008.09.025

Todisco, K. M.; Costa, J. M. C. da; Clemente, E. Alterations in carotenoids, phenolic compounds, flavonoids and ascorbic acid contents in red mombin (Spondias purpurea L.) microencapsulated pulp. Journal of Food, Agriculture \& Environment, v.13, p.24-28, 2015.

Waterhouse, A. L.; Laurie, V. F. Oxidation of wine phenolics: A critical evaluation and hypoteses. American Journal of Enology and Viticulture, v.3, p.306-313, 2006.

Yusof, Y. A.; Salleh, F. S. M.; Chin, N. L.; Talib, R. A. The drying and tabletting of pitaya powder. Journal of Food Process Engineering, v.35, p.763-771, 2012. https://doi.org/10.1111/ j.1745-4530.2010.00625.x 